opathy is does not seem to be the essential point to determine, but rather what is the value of his method. If it is a worthy system of healing it should be recognized and used, while if its claims are false it is criminal to allow the prac. tice.

The followers of this "school" affirm that "osteopathy is still in its infancy," and yet they claim that nearly or quite all. diseases are amenable to its infiuence! Diagnoses are made and treatment given by operators who are nominally required to give but twenty (20) months to the study of the method. Those operators are sincere in their belief-the majority of them. Their school teaches them to be quite optimistic in osteopathy and always pessimistic in everything else. It is useless to appear before courts and to affirm that ostenpathy is massage, etc., for this does not affect their claims that they effect cures. Likewise, nothing is gained by placing a dead lamb on the witness' table and challenging the operator to move bones. Such opposition only goes to support their statements that the theories and methods of their practice are not understood.

Usually when scientific claims are made it is customary to furnish the evidence 'for such, but in no osteopathic text-book am I able to find even one original experiment on which a claim is based, and their theory is one which demands physiologic proofs. So far as I know, no osteopathic school gives a course in experimental physiology-the Kirksville school perhaps schedules one, but does not give it. Their "science" is based on theory alone, and yet the operators have pushed forward their views with an enthusiasm which one would expect to be backed by far stronger arguments than the one usually given-"we get results." It would seem that the only reasonable method for determining the value of osteopathy lies in a thorough experimental research of its theories and the fact that this is not done by osteopaths themselves does not relieve the medical profession of this duty.

Osteopathic theories change, and the teachings of a few vears ago are now obsolete-perhaps criticism lias accomplished this-and may not the present claims of osteopaths be decidedly modified if some one who has the time and opportunity will make a complete study of their tenets. 'The results would be interesting - and valuable.

F. F. WAKEFIELD

\section{Straw Charcoal Dressings of the Japanese.}

BRookLYN, N. Y., March 20, 1905.

To the Editor:-I am greatly interested in an item under the above title which appeared in THE Journal, March 4, page 731. In this item credit is given to Surgeon-General Kikusi for having first suggested the use of charcoal for primary dressings in such cases. As you will see by enclosed extract from reprint of a paper read at the International Medical Congress in London, 1881, I must lay claim to originality as to suggestion and technic, viz.: "I believe a large amount of these septic complications is due to the direct infection"; and after some explanatory remarks, urged the following substitute for the ordinary bandaging: "Among almost all continental nations charcoal is largely used, and everywhere available, and easily obtained; I would suggest, then, after operation, the instant envelopment of the wounds, particularly those of the limbs, and especially, as I think, those of the lower limbs, in a sack or bag (a common, small pillowslip would serve) of charcoal, finely pulverized; a fair excess of this to be used, so as to shield and envelop the tissues; the charcoal to be either directly laid on the wound or mediately, a fold of some dressing, gauze, book muslin, or the like, being applied next the surface; this not to be removed for days at a time, except under pressing necessity, and then preferably by a jet of water from some clean source; the same form of dressing to be reapplied thereafter when necessary." The paper mentioned was published in full in the New York Mcdical Journal, October, 1882, under heading, "A Ready and Convenient Antiseptic Dressing for Amputation and Other Open Wounds in Field Hospitals." A supplementary paper on the same subject was published by me in the Medical Record, Jan. $30,1897$.

S. SHerwfill, M.D.
The Oldest New Hampshire Practitioner.

Worcester, Mass., March 21, 1905.

To the Editor:-In The Journal, March 11, 1905, in the list of deaths it is stated that Alvah R. Cummings, M.D. aged 78, Dartmouth Medical College 1853, was the oldest practitioner of New Hampshire and the oldest member of the New Hampshire Medical Society. I wish to correct the last two statements, for, so far as my knowledge goes. that honor belongs to my friend and former colleague, William Waterhouse, M.D., of Barrington, N. H., now in his eighty-ninth year. He was born Aug. 28, 1816, graduated from the Medical Department of the University of New York in 1842, and joined the New Hampshire Medical Society in 1860, twentyone years before Dr. Cummings joined the same society. Dr Waterhouse has been in constant practice up to within a year and is now enjoying good health. $\mathrm{He}$ is ten years the senior of the late Dr. Cummings.

R. J. WARD.

\section{Memorial to Dr. N. S. Davis.}

HaRTFORd, CONn., March 20, 1905.

To the Editor:-The American Medical Society for the Study of Alcohol and Other Narcotics has arranged to hold a memorial meeting in memory of the late Dr. N. S. Iavis of Chicago at Portland, Ore., July 11, 1905. An entire evening will be devoted to commemorative addresses and papers on the life and work of Dr. Davis, Dr. H. O. Marcy, Boston, will deliver a memorial oration, which will be followed by addresses by Drs. Webster, Hall, Crothers, Hollister, Didama and others. Arrangements are being made to establish a memorial lectureship to the work and memory of Dr. Davis to be deliv. ered annually at the sessions of the Association.

T. D. Crothers.

\section{An Explanation.}

Louisvir.te, KY., March 29 , 1905 .

To the Editor:-In our efforts to place before the medical profession testimony of the highest character from physicians who have used our preparations (formula published), we issued postal cards bearing a testimonial given us several years ago by Dr. Lewis S. McMurtry, President-elest of the American Medical Association. Dr. MeMurtry was not aware that these cards were issued, and, of course, had never given his consent or approval. On receiving a protest from him. we immediately ceased issuing the objectionable cards, and we desire to offer voluntarily this explanation.

George A. Newman Co.

By Addison Dimmitr, Sec'y.

\section{Praises Improved Arrangement of Journal Digest.}

Lawrence, Mass., March 21, 1905.

To the Editor:-I can not forbear expressing my satisfaction at the changed position of digest and contents in ThE Journal. The placing of the second page of contents directly after the first without intervention of advertisements is much more convenient and professional in appearance.

\section{W. H. MERRTL., M.D}

\section{Association News}

\section{Portland Session Worth Attending at Great Trouble and Expense.}

From both points of view-the opportunities of the session and the attractiveness of the trip-the Portland session should be one of the most largely attended in the history of the Association, predicts the Medical Fortnightly. No argument is needed to convince regular and occasional attendants that the scientific worth of the sessions wherever held, always abundantly repay for all expenses and inconveniences incurred; the Portland session will be no exception to this rule, the program promised will be interesting and instructive in a high degree to workers in all lines of medical science- $a$ better has never been prepared; add to this 